\title{
The elasticity of tobacco demand in Australia
}

Caroline Kartika Joe, Chuanling Wei, Mengtian Li, Qingbo Dai

\begin{abstract}
This paper examines the elasticity of demand of tobacco products in Australia from 2000 to 2011. The hypothesis is that the demand for cigarettes is inelastic. The alternate hypothesis is that the demand for cigarettes is elastic. The hypothesis implies that increasing tobacco tax decreases government tax revenue, while the opposite is true for a decrease in tobacco tax. This paper obtains data mainly from Australian Bureau of Statistics and Cancer Council Victoria. We find an increase in the excise rate and government revenue from tobacco products, therefore implying that the demand of tobacco products in Australia is inelastic. We find further support of this finding by examining factors such as the age and income structure of the population.
\end{abstract}




\section{Introduction and Hypothesis}

The World Health Organization recommends that every country increase their regulation of tobacco companies (WHO 2013). One of the common government regulations used to reduce tobacco consumption is the tax. Based on theory, the elasticity of demand for tobacco can be inferred by changes in revenue and price.

The hypothesis of this paper is: the elasticity of demand of tobacco products in Australia is inelastic. The alternative hypothesis is: demand of tobacco products in Australia is elastic. In order to test our hypothesis, we observed the pattern of excise tobacco tax and government tax revenue from tobacco products. Then, we make further inference on tobacco consumption based on the age and income level of the population. The hypothesis will be accepted if the increase of excise tobacco rate leads to the increase of government tax revenue from tobacco products. The alternate hypothesis will be accepted if the increase of excise tobacco rate results in a decrease in government tax revenue from tobacco products.

\section{Theory}

According to standard economic theory (e.g. Mctaggart, Findlay and Parkin (2010, p.86-88)), the elasticity of demand is determined by the percentage changes of quantity demanded and price of the product. The formula to determine the elasticity of demand is:

$$
\begin{gathered}
\text { Price elasticity of } \\
\text { demand }(\mathrm{PEoD})
\end{gathered} \quad=\quad \frac{\% \text { change in quantity demanded }}{\% \text { change in price }}
$$

If the price elasticity of demand is equal to $1(\mathrm{PEoD}=1)$, it means the demand is unit elastic. If the price elasticity of demand is between 0 (zero) and $1(\mathrm{PEoD}<1)$ then the products is said to have an inelastic demand. If the price elasticity of demand is greater than $1(\mathrm{PEoD}>1)$, the products is said to have an elastic demand. 
Figure 1. Elasticity and Total Revenue

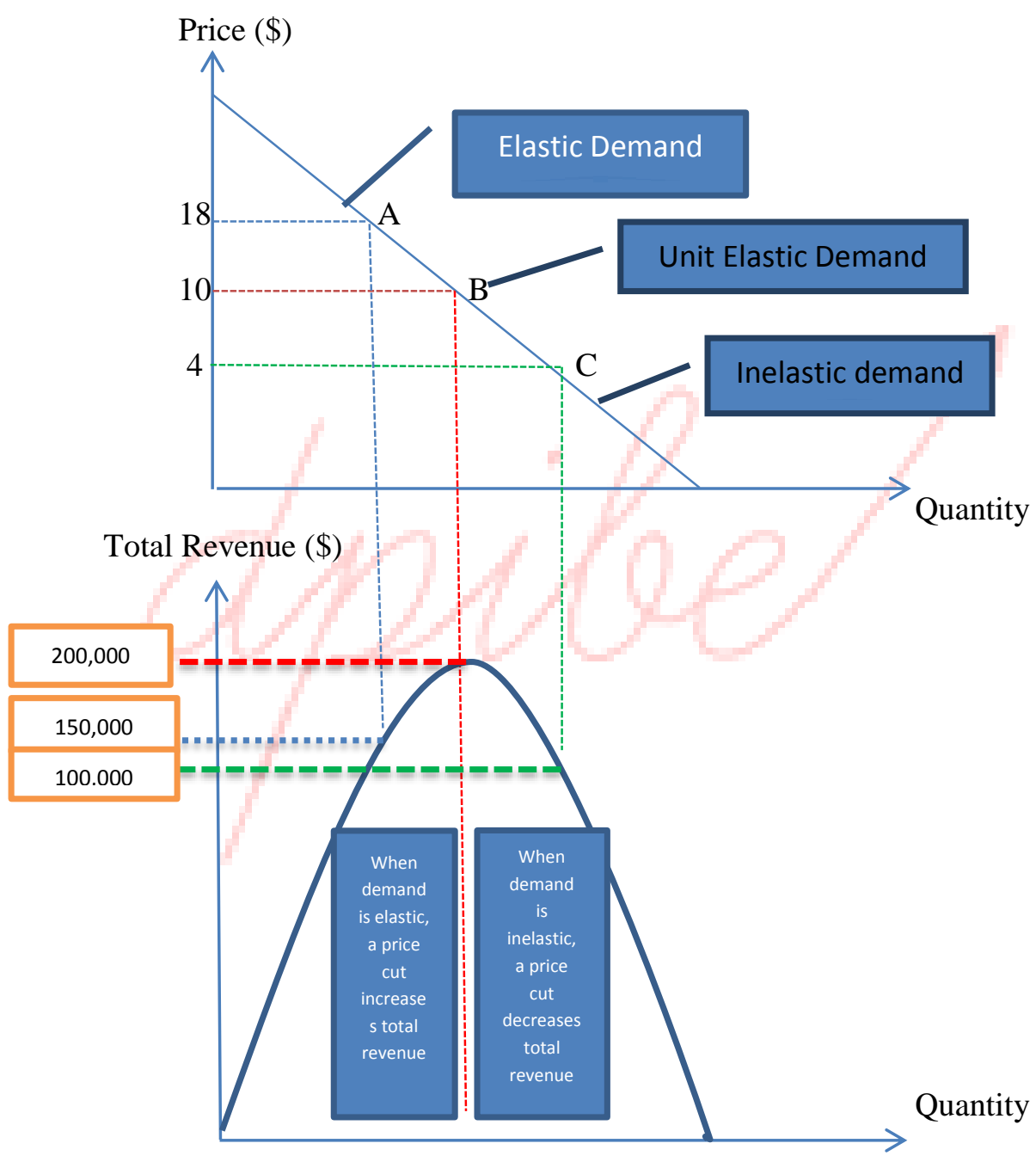

Source: Mctaggart, Findlay and Parkin (2010, p. 88) 
One can infer the elasticity of demand of a product from the increase and decrease of quantity of demand and total revenue. In line with figure 1 , if the price increases from point B to point $\mathrm{A}$ and the result is a decrease in total revenue, we can infer that demand is elastic. On the other hand, if price increases from point $\mathrm{C}$ to point $\mathrm{B}$ and there is an increase in total revenue, we can infer that demand is inelastic.

The elasticity of demand of tobacco products can be influenced by age. Ding (2003, p. 116) asserted that there are two reasons wherein age can determine the elasticity of demand of tobacco products. These reasons are the level of addiction and peer pressures which resulted in different elasticity between youngsters and seniors. Ding (2003, p. 117) contended that youngsters are less addicted to tobacco products and smoke to socialize. From these characteristics, youngsters tend to halt smoking when the price increases. Research from Kostova, Ross, Blecher and Markowitz (2011, p. 423) resulted that the young smokers have high price responsiveness with elasticity of demand ranged from -0.7 to -1.44 .

The second factor that impacts the elasticity of demand of tobacco products is income level. Sylvain (n.d.) asserted that tobacco tax might not reduce tobacco consumption in adult smokers because the tobacco tax only represents a small proportion of their income. In addition, Farrelly, Nonnemaker and Watson (2012) cited that low income groups are more sensitive to cigarette price hikes. This research aligned with Kostova, Ross, Blecher and Markowitz (2011, p. 423) who stated that low and middle income countries have more income restraints than high income countries. Hence, low income countries decrease tobacco consumption if there is an increase in tobacco price.

\section{Literature Review}

Sunley, Yurekli and Chaloupka (n.d.) investigated the outcome of the government revenue generating from an increase of tobacco excise around the whole world. They found a $10 \%$ 
increase in cigarette taxes globally would lead to a reduction of just over 3\% in total cigarette consumption and an approximately $7 \%$ increase of cigarette tax revenues by collecting data of tax revenues, tax rates and prices. High-income nations experience relatively larger increase in government tobacco tax revenues while low-income and middle-income countries have a relatively smaller increase. This is because short run price elasticity of demand for cigarettes in low and middle income countries (-0.8) is relatively less inelastic than high income countries $(-0.4)$. Meanwhile, the tobacco tax in low and middle income countries are lower than in highincome countries.

Ahsan et al. (2013) concluded that cigarette consumption was sensitive to both price and income level. They also found that an increase of tobacco tax rate by $57 \%$ and $70 \%$ will lead to an increase in government revenue by $58 \%$ and $84 \%$ respectively.

Reed (2010) revealed that the tobacco tax had a positive effect on the entire economy. They found that a 5\% increase of tobacco price resulted in $£ 10.2$ billion of economy benefits and around $£ 520 \mathrm{~m}$ revenue gain per year in the first five years on average to the government. They also found all their price elasticity estimates were between zero and -1 . This implies that an increase in the price of tobacco products always leads to an increase in revenue.

Doran et al. (2010) explored the implications on tobacco-related government tax revenue due to the increasing tax collection on tobacco in Vietnam. They used data from the General Office and the Asian Development Bank, making a conclusion that cigarette taxation growth can be regarded as an effective way to curb tobacco consumption and boost the Vietnamese government revenue simultaneously.

Callison and Kaestner (2014, p. 156) contended that an increase of tobacco excise rate will have a stronger effect on adults between 18-34 years old rather than people above 34 years old. A $10 \%$ increase of tobacco excise rate resulted in $0.3-0.7 \%$ decrease for smokers between 18 34 years old; $0.2-0.4 \%$ decrease for smokers between $35-54$ years old; and $0.3-0.6 \%$ decrease 
for smokers between 55-74 years old. Overall, the elasticity of demand of tobacco products remains inelastic.

\section{Analysis}

\subsection{Elasticity of tobacco consumption in Australia}

To test our hypothesis, we use average tobacco tax per cigarette for tobacco products which do not exceed $0.8 \mathrm{~g}$ per stick, average tobacco tax per $\mathrm{kg}$ for tobacco products that exceed $0.8 \mathrm{~g}$ and government tax revenue from tobacco products. We then observe the trend of both the tobacco tax (in AUD) and government tax revenue from 2000 to 2011.

Table 1 List of tobacco tax and government revenue from tobacco products

\begin{tabular}{|r|c|c|c|}
\hline Year & $\begin{array}{c}\text { Average tobacco tax per } \\
\text { cigar for cigars that do not } \\
\text { exceed 0.8 g (in AUD) }\end{array}$ & $\begin{array}{c}\text { Average tobacco tax per } \\
\text { kg for cigars exceed 0.8 } \\
\text { g (in AUD) }\end{array}$ & $\begin{array}{c}\text { Government revenue from } \\
\text { tobacco products (in AUD) }\end{array}$ \\
\hline 2001 & 0.2026 & 253.25 & $4,637,480$ \\
\hline 2002 & 0.2106 & 263.25 & $4,840,580$ \\
\hline 2003 & 0.21644 & 270.8 & $5,212,260$ \\
\hline 2004 & 0.221985 & 277.48 & $5,240,000$ \\
\hline 2005 & 0.22768 & 284.6 & $5,293,000$ \\
\hline 2006 & 0.235495 & 294.38 & $5,290,000$ \\
\hline 2007 & 0.24187 & 302.35 & $5,387,000$ \\
\hline 2008 & 0.251035 & 313.81 & $5,657,000$ \\
\hline 2009 & 0.25756 & 321.97 & $5,711,000$ \\
\hline 2010 & 0.297435 & 371.82 & $5,742,000$ \\
\hline 2011 & 0.340535 & 425.69 & $6,420,000$ \\
\hline
\end{tabular}

Source: Scollo and Winstanley 2012 and 2012a 
Based on Table 1, Figures 2 and 3, it is noticeable that both tobacco tax increase continuously from 2000 to 2011. In the similar pattern, government tax revenue surged from around AUD 4.6 million to 6.4 million in 2001 and 2011 respectively. Looking at Table 1 in more detail, there was a slightly drop by AUD 3,000 from 2005 to 2006. However, this decrease is not significant. The result of our analysis suggests that the demand of tobacco products in Australia is inelastic.

Figure 2. Government Revenue from tobacco products and average tobacco tax per cigar for cigars that do not exceed $0.8 \mathrm{~g}$

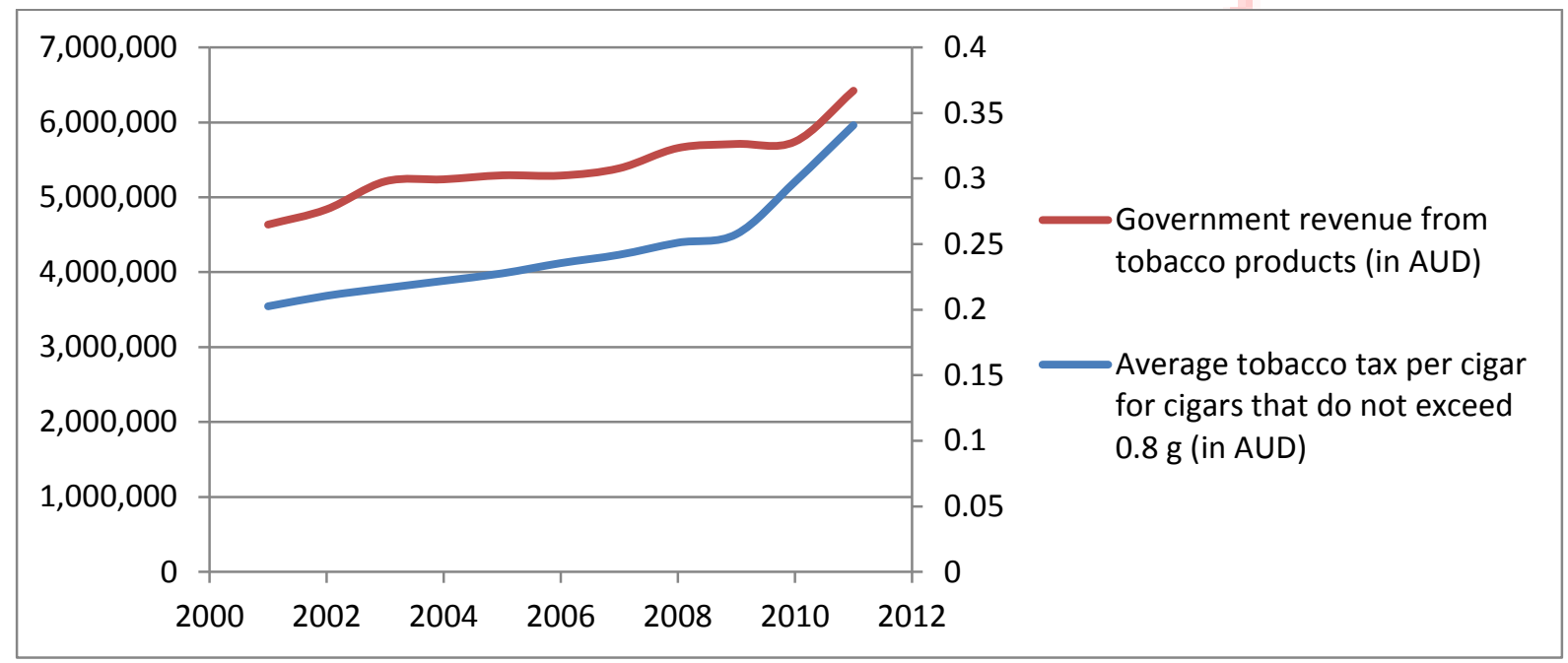


Figure 3. Government Revenue from tobacco products and average tobacco tax per cigar for cigars that exceed $0.8 \mathrm{~g}$

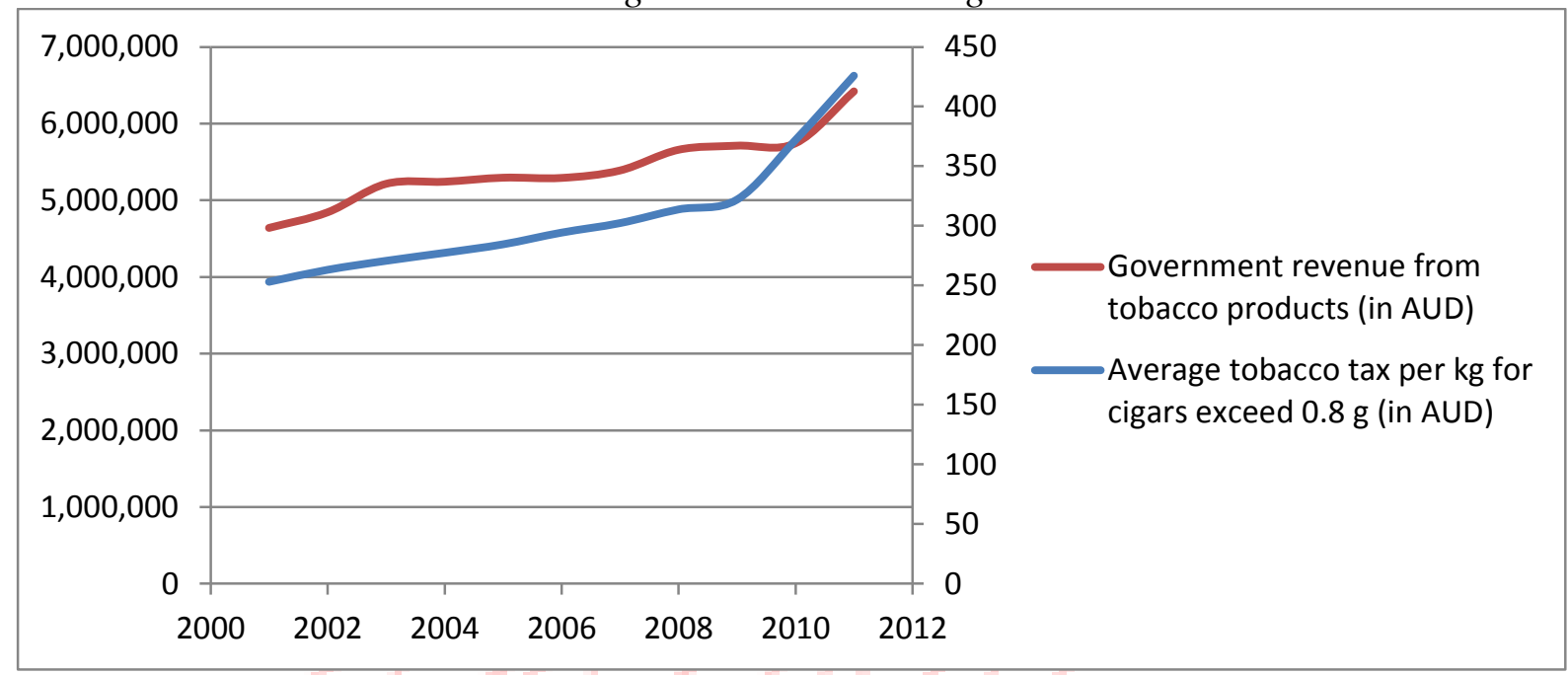

\subsection{Factors contributing to an inelastic demand of tobacco}

To provide further support, we consider two factors which influence the elasticity of demand of tobacco products in Australia. These factors are the age and income level in society.

\section{(1) Age Factor}

In order to evaluate whether the age factor affects the elasticity of demand of tobacco, we collected data about total consumption of cigarettes per week of five age groups in two different years: 2001 and 2010. This data is listed in Table 2. In addition, we also use the changes of price of "Craven A"s from 2001 to 2010. 
Table 2. Total number of cigarettes consumed by different age group in weekly basis

\begin{tabular}{|l|c|c|}
\hline Age & $\begin{array}{c}\text { 2001 (number } \\
\text { of cigarettes) }\end{array}$ & $\begin{array}{c}\mathbf{2 0 1 0} \text { (number } \\
\text { of cigarettes) }\end{array}$ \\
\hline $18-24$ & 12.3 & 11 \\
\hline $25-29$ & 13.5 & 11.2 \\
\hline $30-39$ & 15.9 & 13.6 \\
\hline $40-59$ & 19.6 & 18 \\
\hline $60+$ & 17 & 16.9 \\
\hline Total & $\mathbf{7 8 . 3}$ & $\mathbf{7 0 . 7}$ \\
\hline
\end{tabular}

Source: Scollo and Winstanley 2012b

Table 3. Price of a packet of 20 craven As, Australia, 2000-2010

\begin{tabular}{|r|c|}
\hline Year & Price per pack (\$) (2000 dollars) \\
\hline 2001 & 10.24 \\
\hline 2002 & 10.33 \\
\hline 2003 & 10.45 \\
\hline 2004 & 10.39 \\
\hline 2005 & 11.24 \\
\hline 2006 & 11.51 \\
\hline 2007 & 11.3 \\
\hline 2008 & 11.31 \\
\hline 2009 & 11.87 \\
\hline 2010 & 12.68 \\
\hline
\end{tabular}

Source: Scollo and Winstanley 2012c

Table 3 describes the price of a packet of 20 Craven As from 2001-2010. These prices have been adjusted with the currency in year 2000. In this paper, we will use the price of Craven As in 2001 and 2010 to generate elasticity of demand of tobacco products. The percentage change 
in price (in decimal term) from 2001 to 2010 is $0.2383=((12.68-10.24) / 10.24)$. Then, the percentage change of quantity demanded of tobacco products (in decimal term) from 2001 to 2010 is -0.0971 ((70.7-78.3)/78.3). In calculating the price elasticity of demand, both values will be converted to absolute values which means the minus sign is eliminated.

We can calculate the price elasticity of demand of tobacco products from 2001 to 2010 is 0.4075 (0.0971/ 0.2383). We also provide the elasticity of demand of each age group in 2010 .

Table 4. The changes in quantity demanded of each different age group

\begin{tabular}{|l|l|}
\hline Age & $\begin{array}{l}\text { \% change in Q demand from } \\
\text { 2001 to 2010 in decimal term }\end{array}$ \\
\hline $18-24$ & $(11-12.3) / 12.3=-0.1057$ \\
\hline $25-29$ & $(11.2-13.5) / 13.5=-0.1704$ \\
\hline $30-39$ & $(13.6-15.9) / 15.9=-0.1447$ \\
\hline $40-59$ & $(18-19.6) / 19.6=-0.0816$ \\
\hline $60+$ & $(16.9-17) / 17=-0.0059$ \\
\hline
\end{tabular}

Table 5. The elasticity of tobacco products of different age group

\begin{tabular}{|l|l|}
\hline Age & $\begin{array}{l}\text { \% change in quantity demanded divided by \% change } \\
\text { in price (in decimal term) }\end{array}$ \\
\hline $18-24$ & $0.1057 / 0.2383=0.4436$ \\
\hline $25-29$ & $0.1704 / 0.2383=0.7151$ \\
\hline $30-39$ & $0.1447 / 0.2383=0.6072$ \\
\hline $40-59$ & $0.0816 / 0.2383=0.3424$ \\
\hline $60+$ & $0.0059: 0.2383=0.0248$ \\
\hline
\end{tabular}


Table 4 shows the changes in quantity of different age group from 2001 to 2010 whereas table 5 illustrates the value of elasticity of demand of tobacco products. It is clear that all of these age groups have elasticity value less than 1 .

\section{(2) Income level}

The second factor which influences the elasticity of demand of tobacco products is income level. Some researchers have made conclusions that people from different income levels will response differently in tobacco consumption after the increase of tobacco tax. This is because people in low and middle income level have higher income constraints than people with high income.

Table 6. Average weekly expenditure on tobacco products among households in each income quintile, Australia, 2003-04 and 2009-10 as percentage of total household spending

\begin{tabular}{|l|l|l|l|}
\hline Economic Quintile & $\begin{array}{l}\text { Spending as a \% of total } \\
\text { household expenditure } \\
\mathbf{2 0 0 3 - 2 0 0 4}(\mathbf{a})\end{array}$ & $\begin{array}{l}\text { Spending as a \% of total } \\
\text { household expenditure } \\
\mathbf{2 0 0 9 - 2 0 1 0}(\mathbf{b})\end{array}$ & $\begin{array}{l}\text { Decrease in tobacco } \\
\text { spending (\%) }\end{array}$ \\
\hline Lowest & 1.8 & 1.4 & 0.4 \\
\hline Second & 1.9 & 1.5 & 0.4 \\
\hline Third & 1.5 & 1.3 & 0.2 \\
\hline Fourth & 1.2 & 0.5 & 0.1 \\
\hline Highest & 0.8 & 0.3 \\
\hline
\end{tabular}

(a) Source: Australian Bureau of Statistics 2006

(b) Source: Scollo and Winstanley 2012d

Table 6 describes five different income levels in Australia and its weekly spending for tobacco products in percentage from total income. From Table 1, excise rate for tobacco products increase continuously from 2001 to 2011. In addition, it is assumed that the price of tobacco products also increase aligned with the excise rate. Based on Table 6 , it can be seen that lowest and second income level decreased tobacco consumption by $0.4 \%$ as a total of household expenditure. On the contrary, the third, fourth and highest income level decreased tobacco 
consumption by equal or less than $0.3 \%$. This shows that the lowest and second income levels are more price sensitive compared with third, fourth and highest income level. We conclude that these levels will decrease its tobacco consumption larger than higher income level if there is an increase in tobacco tax.

Table 7. Different income level in Australia in 2009-2010

\begin{tabular}{|l|l|l|l|}
\hline \multicolumn{4}{|c|}{ Mean equivalised disposable household income per week (\$) } \\
$\begin{array}{l}\text { Low } \\
\text { income(a) }\end{array}$ & $\begin{array}{l}\text { Middle } \\
\text { income(b) }\end{array}$ & $\begin{array}{l}\text { High } \\
\text { income(c) }\end{array}$ & $\begin{array}{l}\text { All } \\
\text { households }\end{array}$ \\
\hline 429 & 721 & 1704 & 848 \\
\hline
\end{tabular}

Source: Australian Bureau of Statistics 2012

(a) Persons in the second and third income deciles.

(b) Persons in the middle income quintile.

(c) Persons in the highest income quintile

To support the hypothesis based on income level differences, we also provide total people in every different income level in 2009-2010. The percentage of people in low income level and wealth was exactly $22.6 \%$ of total population. In the opposite, there were $77.4 \%$ $(17.4 \%+17.4 \%+42.6 \%)$ of people in high income level (d) which dominated the income level of Australia. As people in low income level have minor percentage of total population hence a decrease of tobacco consumption from this group will not give significant impact to tobacco demand. Combining the analysis based on Table 6 and 8, it is clear that the decrease of tobacco consumption from people in low income level will not result in a significant decline in government tax revenue. 
Table 8. Income composition and persons in low and not low economic resource group 2009-2010 Source: Australian Bureau of Statistics 2011

\begin{tabular}{|l|l|l|l|l|}
\hline \multicolumn{5}{|l|}{ Persons in low economic resource households, Income, wealth and expenditure - 2009-10 } \\
\hline & $\begin{array}{l}\text { LOW ECONOMIC } \\
\text { RESOURCE } \\
\text { GROUP }\end{array}$ & \multicolumn{1}{|l|}{ NOT LOW ECONOMIC RESOURCE GROUP } \\
\cline { 2 - 5 } & $\begin{array}{l}\text { Low income and } \\
\text { wealth(a) }\end{array}$ & $\begin{array}{l}\text { Low wealth } \\
\text { but not low } \\
\text { income(b) }\end{array}$ & $\begin{array}{l}\text { Low income } \\
\text { but not low } \\
\text { wealth(c) }\end{array}$ & $\begin{array}{l}\text { Not low } \\
\text { income and } \\
\text { not low } \\
\text { wealth(d) }\end{array}$ \\
\hline $\begin{array}{l}\text { Mean weekly } \\
\text { equivalised adjusted } \\
\text { disposable household } \\
\text { income(\$) }\end{array}$ & 465 & 1006 & 494 & 1264 \\
\hline Persons (\%) & f2.6 & 17.4 & 17.4 & 42.6 \\
\hline
\end{tabular}

(a) Persons in the lowest two quintiles of both equivalised adjusted disposable household income (adjusted to include imputed rent) and equivalised household net worth

(b) Persons in the lowest two quintiles of equivalised household net worth and the highest three quintiles of equivalised adjusted disposable household income (adjusted to include imputed rent)

(c) Persons in the lowest two quintiles of equivalised adjusted disposable household income quintiles and the highest three quintiles of equivalised household net worth

(d) Persons in the highest three quintiles of both income and net worth

\section{Limitations}

The key limitation of this paper is the unavailability of data. When we discuss age factors, we only use tobacco consumption of different age group on weekly basis in 2001 and 2010. We also only use the price of Craven As. In terms of income level, we used data of tobacco consumption in 2003-04 and 2009-10 based on economic quintiles. This weakens our results because we only compare two periods of tobacco consumption based on one period income 
structure. To provide more reliable result, we suggest analysing tobacco prices and quantities from the same tobacco brand.

\section{Conclusion}

This paper mainly investigates the elasticity of demand of tobacco products in Australia from 2001 to 2011. The result from our analysis shows that the demand of tobacco products in Australia is inelastic. This finding is supported by the increase of government tax revenue from tobacco products which was aligned with the increase of tobacco excise rate.

In order to support our hypothesis, we took age and income level factors into consideration. More specifically, tobacco consumption decreased slightly based on age group from 2001 to 2010. Based on our analysis, the elasticity of tobacco products in all age groups is less than 1 [<1] from 2001 to 2010. At the same time, compared with smokers in the third, fourth and highest income level, those who are in the lowest and second income levels are more likely to be influenced by the increase of tobacco tax. Since people in low income level represent a small percentage of the total population, there is a little impact on the decrease of tobacco consumption. Therefore, government tax revenue from tobacco continues to increase even as taxes increase.

\section{References}

Ahsan, A, Wiyono, N, Kiting, A, Djutaharta, T and Aninditya, F 2013, Impact of Increasing Tobacco Tax on Government Revenue and Tobacco Consumption, SEADI, retrieved 30 March 2014, $<$ http://www.seadiproject.com/0_repository/SEADI-13-

R120\%20Impact\%20of\%20Tobacco\%20Taxes\%20-\%20Lembaga\%20Demografi.pdf>.

Australian Bureau of Statistics 2006, 'Household expenditure survey, Australia: Summary of results', retrieved 23 April 2014, 
http://www.abs.gov.au/AUSSTATS/abs@.nsf/DetailsPage/6530.0200304\%20\%28Reissue\%29?OpenDocument>.

Australian Bureau of Statistics 2011, 'Feature Article: Low economic resource households', retrieved 17 April 2014,

<http://www.abs.gov.au/AUSSTATS/abs@.nsf/Previousproducts/6554.0Feature\%20Article120 09-10? opendocument \& tabname=Summary \&prodno=6554.0\&issue=2009-10\&num=\&view $>$.

Australian Bureau of Statistics 2012, 'Household income, expenditure and wealth', retrieved 12 July 2014, <http://www.abs.gov.au/ausstats/abs@.nsf/Lookup/by\%20Subject/1301.0 2012 Main\%20Feat ures Household\%20income, \%20expenditure\%20and\%20wealth 193>.

Callison, K and Kaestner, R 2012, Do Higher Tobacco Taxes Reduce Adult Smoking? New Evidence of the Effect of Recent Cigarette Tax Increases on Adult Smoking, the National Bureau of Economic Research, retrieved 22 April 2014, <http://www.nber.org/papers/w18326>.

Ding, A 2003, 'Youth are more sensitive to price changes in cigarettes than adults', The Yale Journal of Biology and Medicine, vol. 76, no. 3, pp. 115-24, retrieved 10 July 2014, $<$ http://eds.b.ebscohost.com/eds/detail?sid=caf51c00-c445-463c-9694$1120 \mathrm{bff5ed} 39 \% 40$ sessionmgr198\&vid=1\&hid=101\&bdata=JnNpdGU9ZWRzLWxpdmUmc2N vcGU9c210ZQ\%3d\%3d\#db=mdc\&AN=15369626>.

Doran, C, Byrnes, J, Higashi, H \& Truong, K 2010, 'Revenue implications to the Vietnamese government of using taxes to curb cigarette smoking', Addictive Behaviors, vol. 35, no. 12, pp 1089-1093, retrieved 2 May 2014, < http://eds.a.ebscohost.com.ezproxyf.deakin.edu.au/eds/detail?vid=3\&sid=93acd15f-ef49-4578-9035a85421e17336\%40sessionmgr4004\&hid=4103\&bdata=JnNpdGU9ZWRzLWxpdmUmc2NvcG U9c210ZQ\%3d\%3d\#db=ccm\&AN=2010797502>.

Farrelly, M, Nonnemaker, J and Watson, K 2012, The Consequences of High Cigarette Excise Taxes for Low-Income Smokers, Public Library of Science, retrieved 23 April 2014, <http://www.plosone.org/article/info\%3Adoi\%2F10.1371\%2Fjournal.pone.0043838>. 
Kostova, D, Ross, H, Blecher, E, \& Markowitz, S 2011, 'Is youth smoking responsive to cigarette prices? Evidenca from low and middle income countries', Tobacco Control, vol. 20, no. 6, retrieved 10 July 2014, pp. 419-424, <http://eds.b.ebscohost.com/eds/detail?vid=3\&sid=d96997b5-650d-4592-872ce 7f67cde0464\%40sessionmgr198\&hid=107\&bdata=JnNpdGU9ZWRzLWxpdmUmc2NvcGU9 c210ZQ\%3d\%3d\#db=lhh\&AN=20113357220>.

McTaggart, D, Findlay, C \& Parkin, M 2010, Economics, $6^{\text {th }}$ edition, Pearson Australia, NSW.

Reed, H 2010, The Effects of Increasing Tobacco Taxation: A Cost Benefit and Public Finances Analysis, Action on smoking and health, retrieved 1 April 2014, <http://www.ash.org.uk/tax/analysis>.

Scollo, MM \& Winstanley, MH 2012, 'Tobacco in Australia: Facts and issues', $4^{\text {th }}$ edn, Cancer Council Victoria, retrieved 16 April 2014, < http://www.tobaccoinaustralia.org.au/13-2tobacco-taxes-in-australia>.

Scollo, MM \& Winstanley, MH 2012a, 'Tobacco in Australia: Facts and issues', $4^{\text {th }}$ edn, Cancer Council Victoria, retrieved 16 April 2014, <http://www.tobaccoinaustralia.org.au/chapter-13taxation/13-6-revenue-from-tobacco-taxes-in-australia>.

Scollo, MM \& Winstanley, MH 2012b, 'Tobacco in Australia: Facts and issues', $4^{\text {th }}$ edn, Cancer Council Victoria, retrieved 16 April 2014, <http://www.tobaccoinaustralia.org.au/chapter-2consumption/2-3-self-reported-measures-of-tobacco-consumption>.

Scollo, MM \& Winstanley, MH 2012c, 'Tobacco in Australia: Facts and issues', $4^{\text {th }}$ edn, Cancer Council Victoria, retrieved 16 April 2014, < http://www.tobaccoinaustralia.org.au/chapter-13taxation/13-3-the-price-of-tobacco-products-in-australia $>$.

Scollo, MM \& Winstanley, MH 2012d, 'Tobacco in Australia: Facts and issues', $4^{\text {th }}$ edn, Cancer Council Victoria, retrieved 18 April 2014, < http://www.tobaccoinaustralia.org.au/chapter-9disadvantage/9-4-the-relationship-between-tobacco-smoking-and-f $>$.

Sunley, E, Yurekli, A, and Chaloupka, F 2010, The design, administration, and potential revenue of tobacco excises, Worldbank, retrieved 30 March 2014, 
<http://siteresources.worldbank.org/INTETC/Resources/3759901089904539172/407TO426.PDF>.

Sylvain, S n.d., The Effects of Excise Tax on Cigarette Consumption:A Divergence in the Behavior of Youth and Adults, Massachusetts Institute of Technology, retrieved 22 April 2014,

< http://www.michiganjb.org/issues/2/article4.pdf >.

World Health Organization 2013, 'WHO report on the global tobacco epidemic 2013: Enforcing bans on tobacco advertising, promotion and sponsorship', retrieved 8 July 2014 , <http://www.who.int/tobacco/global_report/2013/en/>. 